\title{
Effectiveness of Group Logotherapy on Meaning in Life in Mothers of Children with Autism Spectrum Disorder: A Randomized Clinical Trial
}

\author{
Soada Mihandoust ${ }^{1(D)}$, Moloud Radfar ${ }^{1 *}$ (iD), Mehran Soleymani ${ }^{2}$ id \\ 1. Dept.of Nursing,Faculty of Nursing and Midwifery, Urmia University of Medical Sciences, Urmia, Iran \\ 2. Dept. of Psychology, Faculty of Education and Psychology, Azarbaijan Shahid Madani University, Tabriz, Iran
}

\begin{tabular}{|c|}
\hline Article Info \\
\hline doi $10.30699 /$ jambs.29.132.54 \\
\hline $\begin{array}{l}\text { Received: } 2020 / 04 / 27 \\
\text { Accepted: } 2020 / 08 / 02 ; \\
\text { Published Online: } 18 \text { Nov } 2020\end{array}$ \\
\hline $\begin{array}{l}\text { Use your device to scan and read the } \\
\text { article online }\end{array}$ \\
\hline 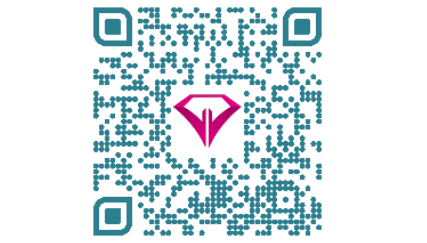 \\
\hline
\end{tabular}

Corresponding Information: Moloud Radfar,

Dept.of Nursing,Faculty of Nursing and Midwifery,Urmia University of Medical Sciences, Urmia, Iran. E-Mail:

radfar.m@,umsu.ac.ir

\begin{abstract}
Background \& Objective: Autism spectrum disorder (ASD) has three key features, i.e., disorders in social interactions, reciprocal communication problems, and restricted, repetitive behavioral patterns. A child with ASD affects parents and could create tension for parents. Making meaning in life can help parents cope with stressful events. Therefore, the current study aimed to assess the effectiveness of group logotherapy on the meaning of life of mothers of children with ASD.
\end{abstract}

Materials \& Methods: This study was a randomized clinical trial incorporating a pre-test, post-test, and control group. To this end, 40 mothers of children with ASD were selected and randomly allocated into two experimental $(\mathrm{n}=20)$ and control groups $(\mathrm{n}=20)$. The Meaning in Life Questionnaire (MLQ) was used to collect data. The research group received ten sessions of 90 minutes logotherapy twice per week, and the control group received a routine intervention. Data were statistically analyzed using SPSS software, along with descriptive statistical, mean, chi-square, Levene's, and $t$ tests.

Results: The results demonstrated significant differences between the experimental and control groups in the mean score of meaning in life after administering logotherapy intervention $(P<0.001)$.

Conclusion: The results indicated that group instruction using the logotherapy approach affected the meaning in life of mothers of children with ASD.

Keywords: Autism Spectrum Disorders, Logotherapy, meaning in life, Group therapy

\section{Introduction}

Autism spectrum disorder (ASD) is a group of syndromes related to neurodevelopmental problems characterized by a wide range of impairments related to social communication and restricted and repetitive behaviors. According to the Diagnostic and Statistical Manual of Mental Disorders (fifth edition, DSM-5), diagnostic criteria for ASD include defects in social interactions and limited interests that occur early in the developmental period (in mild cases); these issues might not be detected for years (1).

Some studies have reported that $1 \%$ of the world's population suffers from this disease (2). New reports of the Centers for Disease Control and Prevention (CDC) have presented more comprehensive degrees of the prevalence of ASD (i.e., one child in every 59 children up until 2014) (3). The World Health Organization (WHO) has estimated the rate of ASD in the world to be one in every 160 children (4). Over the past five years, the prevalence of ASD in Asian countries has increased from 5.19 in 10000 to 7.86 in 10000 . The prevalence of autism in 2009 in the US was estimated to be one case in every 99 children; this rate increased to one case in every 68 children by $2014(5,6)$. Samadi et al. (2012) reported that the rate of autism prevalence in Iran was 6.26 in every 10000 cases (7). The parents of these children experience difficulties and problems in taking care of their children and in their parenting skills in general due to the behavioral abnormalities of their children. They must constantly adjust themselves to meet the child's changing needs. Moreover, a child with ASD, as a mental pressure to parents, reduces parents' abilities to cope with the child's problems (8). Researchers have shown that mothers of children with autism face various challenges. The high volume of painful stimuli damages the mental health of mothers of children with autism.

Theorists have suggested that one of the most important duties of solving problems or difficult events in one's life is developing the comprehension of the events and their concepts or meanings. Researchers have utilized various explanations for this process, such as "finding meaning" (9). 
Finding meaning is one of the most important motivations of human beings, which differentiates us from other beings (10). Finding meaning gives meaning to the life of an individual (11). Finding meaning can increase the ability of an individual to cope with life's problems by creating a sense of purpose and responsibility (12). Having a sense of meaning in life helps people solve life's problems and promotes positive reactions to problems. Therefore, most people understand the concept of a meaningful life as being vital to one's psychological health (13). Jim et al. discovered a relationship between the lack of meaning in life and mental disorders. Feeling a sense of meaning in life was found to have a positive relationship with enjoying one's job, being satisfied with life, and general happiness (14).

Studies have shown that parents (especially mothers of children with autism) often experience difficulties, depression, and suffering; however, some variables can reduce the negative effects of having children with autism. One of these variables (which was investigated in this study) is logotherapy. This approach deals explicitly with human pain $(\mathbf{1 5}, 16)$.

Logotherapy is a psychological school founded by Viktor Emil Frankl. Logotherapy is derived from the term "logos," a Greek word that translates to "meaning" (17). Logotherapy servers as a guide for helping people find meaning and values that are hidden in the critical phases of life so that they can accept and deal with them. The purpose of logotherapy is to enable people to overcome pain and guilt so that they can discover the meaning of life (18). The training logotherapy program is a set of organized activities based on logotherapy techniques having 11 purposes: acquaintance with meaning and meaning sources, finding meaning through love, finding meaning in pain, finding meaning through creativity values, finding meaning through enjoying from doing work, finding meaning through experimental values, creating the ability to move beyond self and laughing to problems, finding meaning through referring to the past, increasing the responsibility to find meaning in the present, reviewing the resources of finding meaning and its conformity with the life of members, and training the opposition intention technique to cope with hopelessness (19).

Falahzade et al., in a piece of interventional research, aimed at investigating the effect of logotherapy on the life and performance of mothers having children with ASD. They concluded that logotherapy facilitates mothers' psychological adjustment and reduces the effect of disturbing thoughts on their mental health status by creating a powerful feeling of meaning and purpose (20).

There are several reasons for the use of logotherapy in this study. First, logotherapy has yielded several specific, well-known therapeutic techniques, such as Hutzell (1990) logotherapy. Second, researchers should continue to investigate logotherapy techniques in different cultures (21). Third, several assessment techniques have come from the work of logotherapists. Additionally, to date, the use of logotherapy has been extremely limited and remained virtually untested (22).

Finally, because autistic children's parents (especially mothers) need counseling and psychotherapy services to cope with their problems, logotherapy sessions must be available for them to extend their sense of meaning in life. Considering the importance of the stated issue, this study aimed to determine the effect of group logotherapy on the meaning in life of mothers of children with ASD.

\section{Materials and Methods}

This study was a clinical trial research with control and intervention groups. This article was a part of the project approved by the Medical University of Urmia; the project code provided by the Ethical Committee is IR.UMSU.REC.1396.282, and the clinical trial code is IRCT20140212016564N11. Having obtained the ethical code and introductory letter, the researcher referred to the Pishgaman-e Omid Center of Urmia. After obtaining the confirmatory note of the manager of the center, as well as the consent of the mothers to participate in the research, a list of participants was prepared. Using a simple random sampling method and considering the sample volume formula, 40 mothers (mean age $=35$ years) were selected; 20 individuals were placed in each group using random replacement.

The studied population included all mothers of the Pishgaman-e Omid Center with children with ASD aged 3 to 15 years. Inclusion criteria included having a child with autism (confirmed and documented by a psychologist), having at least third grade of middle school education, and not having other serious physical or mental diseases (according to the mother herself). Exclusion criteria included the absence from group therapies for more than two sessions and simultaneously participating in the psychotherapy or group and individual counseling sessions of another person.

The instruments used in the current study included the Meaning in Life Questionnaire (MLQ) and researcher-made questionnaire for investigating the demographic characteristics of mothers (without mentioning their names).

MLQ, designed by Steger and Frazier (23), has 10 items that are responded to using a 7-point Likert scale (with responses ranging from $1=$ "completely wrong" to $7=$ "completely correct"). This questionnaire has two sub-scales of "the existence of meaning in life" and "searching for finding meaning." The validity of the tool in Iran was verified by Mesr Abadi et al. (2013), who reported internal validities of 0.63 and 0.87 , respectively, for the existence of meaning and searching for meaning sub-scales (24). 
After selecting the samples, in an explanatory session, the questionnaires, demographic characteristics, and personal satisfaction forms were filled out.

The subjects of the intervention group participated in the programs and logotherapy sessions in the Pishgaman-e Omid Center in the morning. The session was managed such that subjects (intervention group) received homework every session so that they could think it over in the interval between the two sessions and could comment on it in the next session.

Logotherapy has yielded several specific, wellknown therapeutic techniques. Hutzell logotherapy (1990) is one of the most often used logotherapy techniques (21). Ten Hutzell logotherapy sessions (19) were administered (two sessions per week), with each session lasting 90 minutes. The control group received the current programs, including introduction classes with the current center therapies, such as speech therapy, occupational therapy, play therapy, and nutrition therapy, as well as counseling sessions related to the problems of themselves or their children. In consideration of the ethical principles of the study, after completing the intervention and follow-up, logotherapy training was provided to the control group over five sessions (one hour per session).

The data were collected using MLQ, and a post-test was performed on subjects one week after the end of the sessions. Data were statistically analyzed using SPSS 20 (SPSS Inc., Chicago, Ill., USA), along with descriptive statistical, mean, chi-square, Levene's, and $t$ tests.

\section{Table 1. Content of logotherapy sessions for the intervention group}

\begin{tabular}{|c|c|}
\hline Sessions & Content of sessions \\
\hline First & $\begin{array}{l}\text { Mutual introduction between group members and the researcher, determining the purposes and } \\
\text { group rules and administering educational sessions, getting to know the logotherapy approach and } \\
\text { explaining the understanding technique of the values }\end{array}$ \\
\hline Second & Discovering creative values and experimental ones \\
\hline Third & Discovering attitude values \\
\hline Fourth & Creating a hierarchy of values \\
\hline Fifth & Extending value hierarchy, determining actual purposes \\
\hline Sixth & $\begin{array}{l}\text { Analyzing and understanding purposes and investigating them regarding their fitness to personal } \\
\text { values }\end{array}$ \\
\hline Seventh & Evaluating the proportionality of the selected purposes with value hierarchy \\
\hline Eighth & Designing, programming, administering and evaluating to reach the purposes \\
\hline Ninth & $\begin{array}{l}\text { Analysis of the status: identifying strength and weak points of the self (explaining the good deeds } \\
\text { and defects) while reaching to previously determined purposes }\end{array}$ \\
\hline Tenth & Summarizing and reviewing the sessions, responding to the participants' questions \\
\hline
\end{tabular}




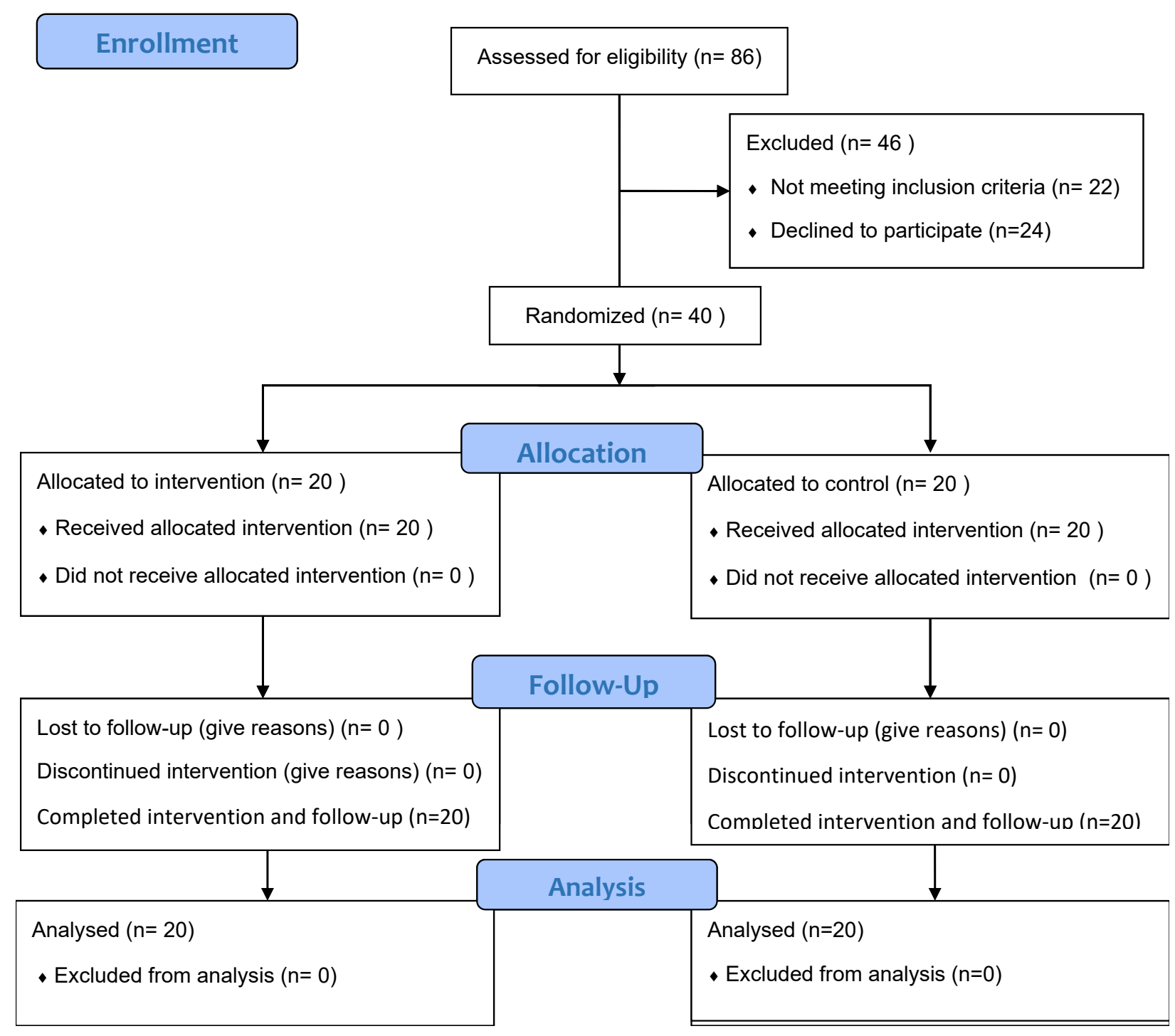

Figure 1. Effect of Isc/R and NAR

\section{Results}

In this study, the results of Table 2.3 indicated that there were no statistically significant differences in demographic characteristics between the two study groups $(P>0.05)$; therefore, the two groups were homogeneous in terms of demographic characteristics.

Table 2. Comparing the demographic characteristics of research units between control and intervention groups

\begin{tabular}{cccc} 
Variable & $\begin{array}{c}\text { Control group } \\
\text { The mean and standard } \\
\text { deviation }\end{array}$ & $\begin{array}{c}\text { Intervention group } \\
\text { The mean and standard } \\
\text { deviation }\end{array}$ & $\begin{array}{c}\text { The restul of } \\
\text { independent } t \text {-test }\end{array}$ \\
Mother's age & $36.80 \pm 8.13$ & $33.13 \pm 6.20$ & $\begin{array}{c}\mathrm{t}=1.388 \\
\mathrm{df}=28 \\
\mathrm{P}=0.176 \\
\mathrm{t}=0.863 \\
\mathrm{df}=28 \\
\mathrm{P}=0.863 \\
\mathrm{t}=0.174 \\
\mathrm{df}=28 \\
\mathrm{P}=0.863\end{array}$ \\
$\begin{array}{c}\text { The duration of } \\
\text { detecting autism }\end{array}$ & $8.53 \pm 3.41$ & $8.20 \pm 4.12$ & $4.26 \pm 3.19$ \\
\hline
\end{tabular}


Table 3.Comparison of qualitative demographic characteristics between control and intervention groups

\begin{tabular}{rcccc}
\hline & Variable & & Groups & Result of statistic \\
chi-square test
\end{tabular}

Levene's test results for the control and intervention groups showed that the groups had a similar variance (Table 4). The independent $t$ test results indicated that before administering the logotherapy intervention, the mean of meaning in life had no significant differences between the control and intervention groups $(P=0.772)$; however, after administering logotherapy intervention, there was a significant difference between the groups $(P=0.000)$.

Levene's tests for the two sub-scales of "finding meaning in life" and "the amount of one's life's meaningfulness" showed the homogeneity of variances. The independent $t$ test also showed that the P-value was less than 0.05 after the intervention ( $P=0.000$ for both).

Table 4. omparing the mean of meaning in life score and two sub-scales before and after the intervention between control and intervention groups

\begin{tabular}{|c|c|c|c|c|c|}
\hline Variable & Phase & $\begin{array}{l}\text { Control group } \\
\text { The mean and } \\
\text { standard } \\
\text { deviation }\end{array}$ & $\begin{array}{l}\text { Intervention } \\
\text { group } \\
\text { The mean and } \\
\text { standard } \\
\text { deviation }\end{array}$ & $\begin{array}{l}\text { The restul of } \\
\text { independent t- } \\
\text { test }\end{array}$ & Levene test \\
\hline \multirow{2}{*}{ Meaning in life } & $\begin{array}{l}\text { Before the } \\
\text { intervention }\end{array}$ & $45.53 \pm 10.36$ & $46.46 \pm 6.73$ & $\begin{array}{c}\mathrm{t}=1.388 \\
\mathrm{df}=28 \\
\mathrm{P}=0.176\end{array}$ & $\begin{array}{l}F=0.761 \\
P=0.390\end{array}$ \\
\hline & $\begin{array}{l}\text { After the } \\
\text { intervention }\end{array}$ & $48.46 \pm 5.78$ & $59.60 \pm 6.42$ & $\begin{array}{c}\mathrm{t}=-4.990 \\
\mathrm{df}=28 \\
\mathrm{P}=0.000\end{array}$ & $\begin{array}{l}\mathrm{F}=0.232 \\
\mathrm{P}=0.634\end{array}$ \\
\hline \multirow{2}{*}{$\begin{array}{c}\text { Finding meaning in } \\
\text { life }\end{array}$} & $\begin{array}{l}\text { Before the } \\
\text { intervention }\end{array}$ & $23.64 \pm 5.32$ & $24.53 \pm 4.12$ & $\begin{array}{c}\mathrm{t}=-0.505 \\
\mathrm{df}=27 \\
\mathrm{P}=0.671\end{array}$ & $\begin{array}{l}F=0.346 \\
P=0.561\end{array}$ \\
\hline & $\begin{array}{l}\text { After the } \\
\text { intervention }\end{array}$ & $25.14 \pm 3.25$ & $30.71 \pm 3.36$ & $\begin{array}{c}\mathrm{t}=4.456 \\
\mathrm{df}=26 \\
\mathrm{P}=0.000\end{array}$ & $\begin{array}{l}F=1.786 \\
P=0.895\end{array}$ \\
\hline
\end{tabular}




\begin{tabular}{|c|c|c|c|c|c|}
\hline & & Control group & $\begin{array}{l}\text { Intervention } \\
\text { group }\end{array}$ & \multirow{2}{*}{$\begin{array}{l}\text { The restul of } \\
\text { independent } t- \\
\text { test }\end{array}$} & \multirow[b]{2}{*}{ Levene test } \\
\hline Variable & Phase & $\begin{array}{c}\text { The mean and } \\
\text { standard } \\
\text { deviation }\end{array}$ & $\begin{array}{c}\text { The mean and } \\
\text { standard } \\
\text { deviation }\end{array}$ & & \\
\hline \multirow{2}{*}{$\begin{array}{c}\text { The amount of } \\
\text { meaningfulness of } \\
\text { one's life }\end{array}$} & $\begin{array}{l}\text { Before the } \\
\text { intervention }\end{array}$ & $24.00 \pm 5.74$ & $22.84 \pm 5.42$ & $\begin{array}{c}\mathrm{t}=0.664 \\
\mathrm{df}=28 \\
\mathrm{P}=0.512\end{array}$ & $\begin{array}{l}\mathrm{F}=0.012 \\
\mathrm{P}=0.912\end{array}$ \\
\hline & $\begin{array}{l}\text { After the } \\
\text { intervention }\end{array}$ & $23.60 \pm 3.04$ & $30.74 \pm 3.36$ & $\begin{array}{c}\mathrm{t}=-5.983 \\
\mathrm{df}=27 \\
\mathrm{P}=0.000\end{array}$ & $\begin{array}{l}F=0.043 \\
P=0.838\end{array}$ \\
\hline
\end{tabular}

\begin{tabular}{|c|c|c|c|c|c|}
\hline Variable & Phase & $\begin{array}{c}\text { Control } \\
\text { group } \\
\text { The mean } \\
\text { and standard } \\
\text { deviation }\end{array}$ & $\begin{array}{l}\text { Intervention } \\
\text { group } \\
\text { The mean and } \\
\text { standard } \\
\text { deviation }\end{array}$ & $\begin{array}{l}\text { The difference } \\
\text { between scores }\end{array}$ & $\begin{array}{l}\text { Paired t- } \\
\text { test }\end{array}$ \\
\hline \multirow{2}{*}{ Meaning in life } & $\begin{array}{l}\text { Control } \\
\text { group }\end{array}$ & $47.73 \pm 6.25$ & $47.73 \pm 6.31$ & $0.00 \pm 0.06$ & $\begin{array}{c}\mathrm{t}=0.000 \\
\mathrm{df}=14 \\
\mathrm{P}=0.999\end{array}$ \\
\hline & $\begin{array}{l}\text { Intervention } \\
\text { group }\end{array}$ & $37.46 \pm 6.89$ & $53.73 \pm 6.22$ & $-16.26 \pm 0.67$ & $\begin{array}{c}\mathrm{t}=-6.936 \\
\mathrm{df}=14 \\
\mathrm{P}=0.001\end{array}$ \\
\hline \multirow{2}{*}{$\begin{array}{l}\text { Finding meaning } \\
\text { in life }\end{array}$} & $\begin{array}{l}\text { Control } \\
\text { group }\end{array}$ & $23.25 \pm 5.69$ & $25.25 \pm 3.19$ & $-2.00 \pm 2.50$ & $\begin{array}{c}\mathrm{t}=-1.331 \\
\mathrm{df}=11 \\
\mathrm{P}=0.210\end{array}$ \\
\hline & $\begin{array}{l}\text { Intervention } \\
\text { group }\end{array}$ & $23.86 \pm 3.79$ & $30.73 \pm 3.23$ & $-6.86 \pm 0.56$ & $\begin{array}{c}\mathrm{t}=-6.653 \\
\mathrm{df}=14 \\
\mathrm{P}=0.001\end{array}$ \\
\hline \multirow{2}{*}{$\begin{array}{c}\text { The amount of } \\
\text { meaningfulness of } \\
\text { one`s life }\end{array}$} & $\begin{array}{l}\text { Control } \\
\text { group }\end{array}$ & $23.57 \pm 5.70$ & $23.50 \pm 3.13$ & $00.07 \pm 2.57$ & $\begin{array}{c}\mathrm{t}=0.069 \\
\mathrm{df}=13 \\
\mathrm{P}=0.946\end{array}$ \\
\hline & $\begin{array}{l}\text { Intervention } \\
\text { group }\end{array}$ & $22.38 \pm 4.90$ & $31.30 \pm 2.83$ & $-8.92 \pm 2.07$ & $\begin{array}{c}\mathrm{t}=-5.332 \\
\mathrm{df}=12 \\
\mathrm{P}=0.001\end{array}$ \\
\hline
\end{tabular}

Paired $t$ tests indicated no significant differences between the mean of the finding meaning scores recorded at the beginning and end of the study in the control group $(P=0.999)$. However, there was a significant difference in the intervention group $(P=0.001)$.

Regarding the two sub-scales of "finding meaning in life" and "the amount of one's life's meaningfulness," no significant differences were observed for the control group when comparing their scores at the beginning and end of the study $(P=0.210$ and $P=0.946$, respectively). However, significant differences were observed in the intervention group for both sub-scales ( $P=0.000$ for both).

In the intervention group, the average scores of the two sub-scales of MLQ were increased after logotherapy training among mothers of children with ASD. Therefore, it is concluded that logotherapy has a positive effect on the amount of meaning in life felt by these mothers. Thus, the research hypothesis was confirmed that logotherapy affects meaning in life in mothers having children with autism.

\section{Discussion}

The current research aimed to determine the effect of logotherapy on the meaning in life of mothers of children with ASD. The research hypothesis was confirmed (i.e., logotherapy affects meaning in life felt by mothers of children with ASD). The findings of the current study corroborated the results of 
previous studies conducted by local and foreign researchers.

Faramarzi and Bavali (2016) carried out a study entitled "The effect of group logotherapy on improving the mental health of mothers having intellectually disabled children." They selected 26 mothers of children with mental disabilities. They concluded that logotherapy-based group training improved the mental health of mothers and could be used to help parents improve their mental health (25).

Azad Yekta (2016) investigated the effectiveness of logotherapy on the mental health of mothers of children with mental disabilities. The results indicated that logotherapy sessions improved the mental health of these mothers. Mothers were made aware that although they cannot change their children's disabilities, they can change their attitudes toward disability. They learned that they can find new meaning in the disability of their children (26).

Chua (2016) published a paper entitled "Finding meaning in life for parents of children with autism spectrum disorders: a salutogenic approach." This approach enabled parents to manage tension using existing resources and supports, as well as effective coping, to find a solution (27). The difference between this study and our study was that we utilized Hutzell's (2002) logotherapy protocol.

Practically, logotherapy helps people, despite their hopelessness, not concentrate on what is missing and instead to seek meaning. In another study, Falahzade et al. (2019) explored the effectiveness of group logotherapy on the meaning of life and family performance of mothers having a child with ASD. A comparison between the two groups showed that group logotherapy increased meaning in life and improved the family performance of mothers in the intervention group. The difference between this study and our research was in the sample volume (eight individuals in the intervention group and 10 individuals in the control group) and research instruments. The questionnaire used in Falahzade et al. 's study was designed by Crambaff and Mahulik (1969), which included 20 items (20).

Yek et al. (2017) investigated the presence of and search for meaning in life and their correlation with health anxiety. In their work, 753 participants completed MLQ and the Short Health Anxiety Inventory. Results indicated that more meaning in life was associated with lower health anxiety. Results also suggested that the presence of meaning in life and the search for meaning in life are correlated with health anxiety (28).

Robatmili et al. (2015) investigated the effect of group logotherapy on the meaning of life and depression in Iranian students. The results indicated that group logotherapy can improve one's sense of meaning in life and reduce depression (29).
Yolme et al. (2020) investigated the effect of Islamic logotherapy training on the self-resilience of 60 mothers with thalassemia. The results showed that this method increased self-resilience among mothers. This study showed that spirituality and religion help patients suffering from a chronic disease to be more adaptable to the disease and feel healthy and satisfied (30).

Training mothers can lead to more comprehension of their children's growth conditions. On the other hand, since training sessions are held in groups and through mutual interaction of the researcher and parents, mothers can state the stress and mental pressures resulting from daily tensions of interacting with children and sympathize with others having the same feelings. In the group training method, members feel more secure and can use each other's experiences and support each other. During sessions, it was observed that group members guided and advised each other; observing and listening to others contrives a way for imitation and modeling of their positive behaviors. An opportunity was also obtained that group members could get aware of each other's feelings and could be encouraged to pay attention to their feelings during the session and talk about them. When they noticed that they could help other members of the group, they felt that they are more valuable.

People listened to others' talks and noticed that they have fears, problems, and concerns similar to the fears, problems, and concerns of themselves. Noticing that they are not alone was charming. Therefore, group therapy reduced seclusion and alienation, which increased the commonness of pain, and tolerating difficulties was made possible for them.

In the current study, subjects were encouraged toward discovering meaning in life, and group logotherapy affected the increase of meaning in the life of mothers having children with ASD. Logotherapy helps individuals find meaning and hidden values in the critical phases of life and enables individuals to accept and overcome it. They can learn how to cope with problems and respond appropriately while facing painful events in life.

This study had limitations: data collection was only possible based on self-report scales, which led to the possibility of having unreal and perverted responses of the subjects. Moreover, another limitation was that subjects were not followed up to see whether the difference between the intervention and control groups continued for a long time because the children's school year was ended, and their mothers did not refer to the center. In order to achieve accurate results, it is suggested that researchers should consider this issue. Considering these limitations, it is recommended that studies are conducted in a wider statistical population of mothers and fathers in other regions, and other psychological variables and data collecting tools should be utilized in future studies. 
Having considered these findings and limitations, it could be stated that group logotherapy increased the meaning in life of mothers of children with ASD. Therefore, it is recommended that logotherapy courses are utilized by rehabilitators and counselors in rehabilitation centers, schools, organizations, and counseling centers.

\section{Acknowledgments}

This study was supported a grant from the Urmia University of Medical Sciences. The authors would like to thank all participants for their cooperation in this study.

\section{Ethical considerations}

Ethical issues (Including plagiarism, informed consent, misconduct, data fabrication and/or falsification, double publication and/or submission, redundancy, etc.) have been completely observed by the authors.

\section{Funding and support}

This research received no specific grant from any funding agency in the public, commercial, or not-forprofit sectors.

\section{Conflict of Interest}

Authors declared no conflict of interest.

\section{References}

1. Sadock B, Ruiz P. Kaplan \& Sadock's synopsis of psychiatry: behavioral sciences: Walters Kluwer; 2015.

2. American Psychiatric Association. Diagnostic and Statistical Manual of Mental Disorders (DSM-5®), Fifth Edition: American Psychiatric Publishing; 2013. [Available from: https://books.google.com/books

3. Christensen DL, Baio J, Van Naarden Braun K, et al. Prevalence and characteristics of autism spectrum disorder among children aged 8 years, autism and developmental disabilities monitoring Network, 11 Sites, United States, 2012. Morbidity and mortality weekly report Surveillance summaries (Washington, DC : 2002). 2016;65(3):123. [DOI:10.15585/mmwr.ss6503a1]

4. WHO. Autism spectrum disorders Geneva, Switzerland. $2018 \quad$ [Available

from: http://www.who.int/en/news-room/factsheets/detail/autism-spectrum-disorders.

5. Donaldson SO, Elder JH, Self EH, Christie MB. Fathers' perceptions of their roles during in-home training for children with autism. J Child Adoles
Psychiatr
Nurs.
2011;24(4):200-7.
[DOI:10.1111/j.1744-6171.2011.00300.x]

6. Chin WC, Chao KY, Chang HL, Li HM, Chen SH. Coping strategies of Taiwanese children with autism spectrum disorders. J Clin Nurs. 2017;26(21-22):3408-21. [DOI:10.1111/jocn.13700]

7. Samadi S, McConkey R. The impact on Iranian mothers and fathers who have children with an autism spectrum disorder. J Intellect Disabil Res. 2014;58(3):243-54. [DOI:10.1111/jir.12005]

8. Yirmiya N, Shaked M. Psychiatric disorders in parents of children with autism: a meta-analysis. Journal of child psychology and psychiatry. 2005;46(1):69-83. 7610.2004.00334.x]

[DOI:10.1111/j.1469-

9. Pakenham KI, Sofronoff K, Samios C. Finding meaning in parenting a child with Asperger syndrome: Correlates of sense making and benefit finding. Res Develop Disabil. 2004;25(3):245-64. [DOI:10.1016/j.ridd.2003.06.003]

10. Galvin L, Godfrey H. The impact of coping on emotional adjustment to spinal cord injury (SCI): review of the literature and application of a stress appraisal and coping formulation. Spinal Cord. 2001;39(12):615. [DOI:10.1038/s].sc.3101221]

11. Fabricatore AN, Handal PJ, Rubio DM, Gilner FH. Stress, religion, and mental health: Religious coping in mediating and moderating roles. Int $\mathrm{J}$ Psychol Religion. 2004;14(2):91-108. [DOI:10.1207/s15327582ijpr1402_2]

12. Robinson S, Dowson P. Responsibility and integrity in the curriculum. J Glob Responsibil. 2011;2(2):253-68. [DOI:10.1108/20412561111166085]

13. Nasiri H, Jokar B. Life meaningfulness, hope, life satisfaction and psychological health in women (a group of working women). Women Studies. 2008;2:157-76.

14. Jim HS, Purnell JQ, Richardson SA, Golden-Kreutz $\mathrm{D}$, Andersen BL. Measuring meaning in life following cancer. Qual Life Res. 2006;15(8):135571. [DOI:10.1007/s11136-006-0028-6]

15. Ogston PL, Mackintosh VH, Myers BJ. Hope and worry in mothers of children with an autism spectrum disorder or Down syndrome. Res Autism Spectr Disorder. 2011;5(4):1378-84. [DOI:10.1016/j.rasd.2011.01.020]

16. Khodabakhshi Ka. Effectiveness of hope-oriented group therapy on life meaning and resilience in mothers with physical-motor disabled children. J Pediatr Nurs.2015;1:15-25

17. Mohammadpour AR. Victor E Frankl: A Review on existential psychology and psychotherapy. Tehran: Danjeh Pub. 2017;2 nd Ed. 
18. Tayyebi Ramin Z, Dadkhah A, Bahmani B, Movallali G. Effectiveness of group logo therapy on increasing the quality of the motherslife of hearing impaired children. Apply Psychol. 2014;6:18-26.

19. Hutzell R. A general course of group analysis. Viktor Frankl Foundation of South Africa. 2002; 7:15-26.

20. Falahzadeh $H$, Nouri $S$, Pourebrahim $T$, Nazarboland N. The effectiveness of group logo therapy on the meaning of life and family functioning for mothers with an Autism Spectrum Disorders Child. J Family Res.2018;14(53):135-50

21. Schulenberg SE, Hutzell RR, Nassif C, Rogina JM. Logotherapy for clinical practice. Psychother Theory, Res, Practice, Training. 2008;45(4):447. [DOI:10.1037/a0014331]

22. Hutzell RR. Meaning and purpose in life: Assessment techniques of logotherapy. Hospice J. 1986;2(4):37-50. 969X.1986.11882574]

23. Steger MF, Frazier P, Oishi S, Kaler M. The meaning in life questionnaire: Assessing the presence of and search for meaning in life. J Counsel Psychol. 2006;53(1):80. [DOI:10.1037/0022-0167.53.1.80]

24. Mesrabadi J, Jafariyan S, Ostovar N. Discriminative and construct validity of meaning in life questionnaire for Iranian students. International Journal of Behavioral Sciences. 2013;7(1):83-90.

25. Faramarzi S, Bavali F. The effectiveness of group logotherapy to improve psychological well-being of mothers with intellectually disabled children. Int $\mathbf{J}$ Develop Disabil. 2017;63(1):45-51. [DOI:10.1080/20473869.2016.1144298]

26. Azadyekta M. Investigating the effectiveness of logotherapy in mental health of mothers with exceptional children. Middle East J Disabil Studies. 2015;5:77-83.

27. Chua Ack. Finding meaning in life for parents of children with autism spectrum disorder: A salutogenic approach. Europ J Special Educat Res. 2016;(1)2;1-12

28. Yek MH, Olendzki N, Kekecs Z, Patterson V, Elkins G. Presence of meaning in life and search for meaning in life and relationship to health anxiety. Psychol Reports. 2017;120(3):383-90. [DOI:10.1177/0033294117697084]

29. Robatmili S, Sohrabi F, Shahrak MA, Talepasand S, Nokani M, Hasani M. The effect of group logotherapy on meaning in life and depression levels of Iranian students. Int J Advance Counsel. 2015;37(1):54-62. [DOI:10.1007/s10447-0149225-0]

30. Yolme ABS, Hojjati H, Akhoundzadeh G. The effect of Islamic semanticism on self-reporting and lifestyles of mothers of adolescents with thalassemia. Int $\mathrm{J}$ Adoles Med Health. 2020;1(ahead-of-print). [DOI:10.1515/ijamh-20190192]

\section{How to Cite This Article:}

Mihandoust S, Radfar M, Soleymani M. Effectiveness of Group Logotherapy on Meaning in Life in Mothers of Children with Autism Spectrum Disorder: A Randomized Clinical Trial. J Adv Med Biomed Res. 2020; 29 (132) :54-62

\section{Download citation:

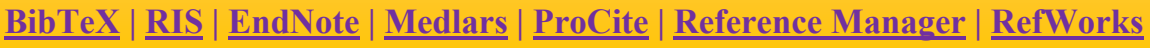

\section{Send citation to:}

8 Mendeley 2 Zotero (-) RefWorks RefWorks 